\title{
Research
}

\section{Pluralism, Resilience, and the Ecology of Survival: Case Studies from the Pamir Mountains of Afghanistan}

\author{
$\underline{\text { Karim-Aly S. Kassam }}^{1}$
}

\begin{abstract}
As resilience is observed under circumstances of systemic stress, the various ecological zones of the Pamir Mountains of Afghanistan and the cultural diversity contained within this milieu provide an appropriate setting from which to ask "How can a dynamic concept of pluralism inform adaptation, survival, and resilience in the face of dramatic socio-cultural and environmental change?" This paper asserts that understanding of resilience in coupled socio-cultural and ecological systems is enhanced by the concept of pluralism. The idea of ecological niche is enriched by sensitivity to culture, religion, ethnicity, lifestyle, and habitat. Facilitative relations between the ethnically diverse Kyrgyz and Wakhi, as well as the Pashtu and Shugni, contribute to their mutual survival and food sovereignty. The common good is achieved by harnessing ethnic, religious, and ecological diversity.
\end{abstract}

Key Words: Afghanistan; Arab Pashtu; coupled systems; human ecology; Kyrgyz; pluralism; Pamir Mountains; resilience; Shugni; Wakhi

\section{INTRODUCTION}

Scholarship on coupled socio-cultural and ecological systems suggests that biocultural diversity can support resilience (Holling 2001, Maffi 2001, Maffi 2002, Maffi 2005, Harmon 2002, Harmon 2007, Berkes et al. 2003, Turner et al. 2003, Chapin et al. 2004, Adger et al. 2005, Folke 2006, Kassam 2009a). Resilience, defined as the capacity of social and ecological systems to absorb disturbance and still retain their basic function and structure (Holling 1973, Folke et al. 2002, Walker and Meyers 2004, Walker and Salt 2006, Miller et al. 2008), is closely linked to the sustainability of cultures, societies, and their respective environments. Although mustering empirical evidence to demonstrate the role of resilience in connecting socio-cultural and ecological systems has been challenging, I suggest that a deeper understanding of resilience may be achieved by incorporating the concept of pluralism. Pluralism asserts diversity, both in the natural environment and in human culture, and recognizes that change is a normal part of ecological and socio-cultural processes. Pluralism not only accepts difference but values it. In the context of social and ecological change, pluralism enables diverse groups to work successfully together in order to realize their common good (Kallen 1915, Engelhardt and Jennings 1989, Schlosberg 1999, Mason 2006). While socio-cultural and ecological diversity are empirical facts, pluralism is normative because it values this diversity and seeks to safeguard it.

Resilience is observed where there is systemic stress. The collapse of the Soviet political and economic structure, the presence of a 30 -year civil war in Afghanistan, and the strategic significance of this region in the global game of alliances combine to form the setting from which to ask "How can a dynamic concept of pluralism inform adaptation, survival, and resilience in the face of dramatic socio-cultural and environmental change?" Pluralism and resilience are best understood in action, not in abstraction. Since the end of the Cold War, international polarization has re-emerged in the form of a "clash of civilizations" (Huntington 1996). This world view uncritically positions diverse Chinese and Muslim cultures as adversaries of the "West". Furthermore, it dismisses the significance of ethnically diverse indigenous cultures globally. Ironically, the frontlines of both the Cold War and the so-called clash of civilizations are being played out in the same strategic region of 
Central Asia. Just as the Cold War was blind to cultural and religious pluralism in the "Communist East" and "Capitalist West", the clash-ofcivilizations approach, while attempting to explain differences, is similarly and willfully blind to religious, cultural, and ecological diversity. It is an outdated paradigm as humanity in the 21 st century faces the challenges of environmental change, economic instability, and religious fanaticism. Evidence from the Pamir Mountains of Afghanistan reveals a narrative of pluralism and resilience under conditions of war, dramatic climate change, and potential food crisis (Kassam 2009b).

Undertaking research in the Afghan Pamirs involves significant risks (International Crisis Group 2009). One result is that despite the considerable media attention the country has received, there are lacunae in the scholarship of recent decades (Fig. 1: Research Area). In the context of increasing vulnerability among the peoples of the Pamirs, there is also evidence of resilient communities building upon their pluralistic ethnic and religious heritage and diverse ecological niches. The goals of this paper are to (1) explore the mechanisms by which pluralism facilitates mutual survival among diverse communities; (2) illustrate that pluralism has an ecological foundation; and (3) further understanding of coupled socio-cultural and ecological systems through the linkage of pluralism to resilience.

The link of pluralism to resilience is still formative. Here I use two case studies from current research in the Pamir Mountains of Afghanistan to explore their connection, demonstrate the complex connectivity between the cultural and the ecological, and tease out conceptual insights on which to anchor the relationship between pluralism and resilience.

\section{METHODS}

In 2006, I interviewed small groups of people from three ethnic origins: Kyrgyz at their summer camp of Tashbulaq, Shugni in the village of Pul-i-Zirebon, and Wakhi in the villages of Sarhad-i-Broghil and Wuzd. Semi-structured group interviews based on action research methods allowed community participants to state their priorities, which guided the research process (Chambers 1997, Greenwood and Levin 1998, Kassam 2009a). These group interviews were followed by individual interviews. In all, 38 individuals, all male, were interviewed as part of this preliminary research. In the course of the interviews, it became clear that the survival of these people in the face of war and the uncertainties of socio-cultural and environmental change depended on mutual support between ethnic groups (Kassam 2009b). In 2008, follow-up interviews were conducted to validate the information from 2006 and pursue the linkage between pluralism, resilience, and adaptation to change. This time, the 61 individuals interviewed included 45 men and 16 women. Ms. Munira Karamkhudoeva, my research assistant, conducted the interviews with the women. In 2009, we conducted additional interviews with Arab Pashtu (13 women and 7 men) while they were in their encampments near Pul-i-Zirebon, as well as more follow-up interviews with the Shugni in Puli-Zirebon ( 9 women and 3 men), a total of 32 individuals. The iterative nature of the interviews facilitated exploration of the rather complex interconnections between pluralism, ecological zones, and adaptation to socio-cultural change. The research was complicated by border crossings from the different regions of the Pamir Mountains in Tajikistan into Afghanistan. In terms of safety and logistics, these were challenging undertakings. This research has also drawn upon previous work by Shahrani (1978, 1979), Barfield (1978, 1981), Kreutzmann (2003), and Felmy and Kreutzmann (2004).

\section{RESULTS}

\section{Illustrative cases}

The dichotomy between nature and culture is not relevant to the context of the diverse peoples of the Pamirs. Socio-cultural and ecological systems are linked through relationships between people and their environment, which includes both relations between humans and relations between humans and other animals, plants, and their habitats (Kassam $2009 a$ ). The complex connectivity of humanecological relations is illustrated by four groups of people in Afghanistan, in the Wakhan corridor and the Badakhshan region south of Lake Shiva, who differ in ethnic origin, occupy different ecological niches, and practice a variety of interpretations of Islam (Fig. 2). The following two case studies mirror each other and provide opportunity for insights.

Because human beings in the Pamirs occupy a dominant position within a mountain ecosystem, their environment offers them a wide variety of resources. As omnivores, humans feed at different 
Fig. 1. Map of research area in the Pamir Mountains of Afghanistan (and Tajikistan) in Central Asia.

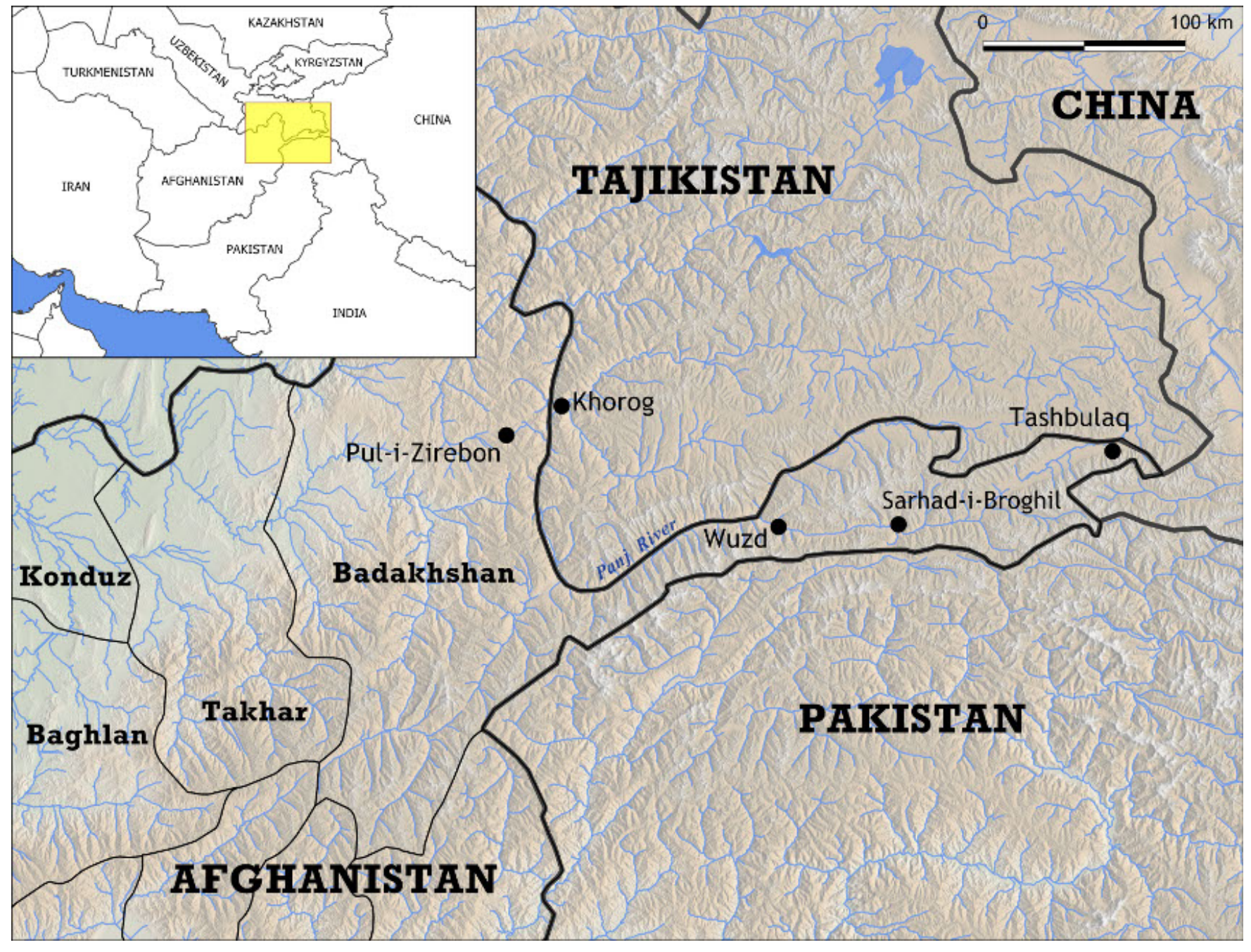

levels of the food chain. As a result, populations of Homo sapiens, like other species, are able to adapt through biological or behavioral adjustments, or both, to meet the demands of their environment. By virtue of their adaptations, species occupy an ecological niche. Odum (1989) described an organism's niche as its "profession" and its habitat as its "address". For Homo sapiens, some of these professions within an ecosystem are forager, fisher, hunter, herder, cultivator, intense agriculturist, and industrialist. The survival and flourishing of humans under varying ecosystems has depended upon the interplay of the socio-cultural with the ecological.

\section{The human ecology of the Wakhi and Kyrgyz}

The Wakhi and Kyrgyz peoples live in the Wakhan corridor, which borders China to the east, Tajikistan to the north, and Pakistan to the south (Figure 2). While the Wakhi are sedentary farmers who keep some animals, the Kyrgyz are nomadic and use large pastures for grazing their herds (Fig. 3). The Wakhi, a distinct ethnic group, undertake irrigated crop farming in valleys between 2500 and 3500 meters above sea level, and grow wheat, barley, millet, peas, and even potatoes, though the potato harvest is not reliable in villages at higher elevations, such as Sarhad-i-Broghil. Often the poorer households 
Fig. 2. Map of ethnic groups in the Pamir Mountains of Afghanistan (and Tajikistan) in Central Asia.

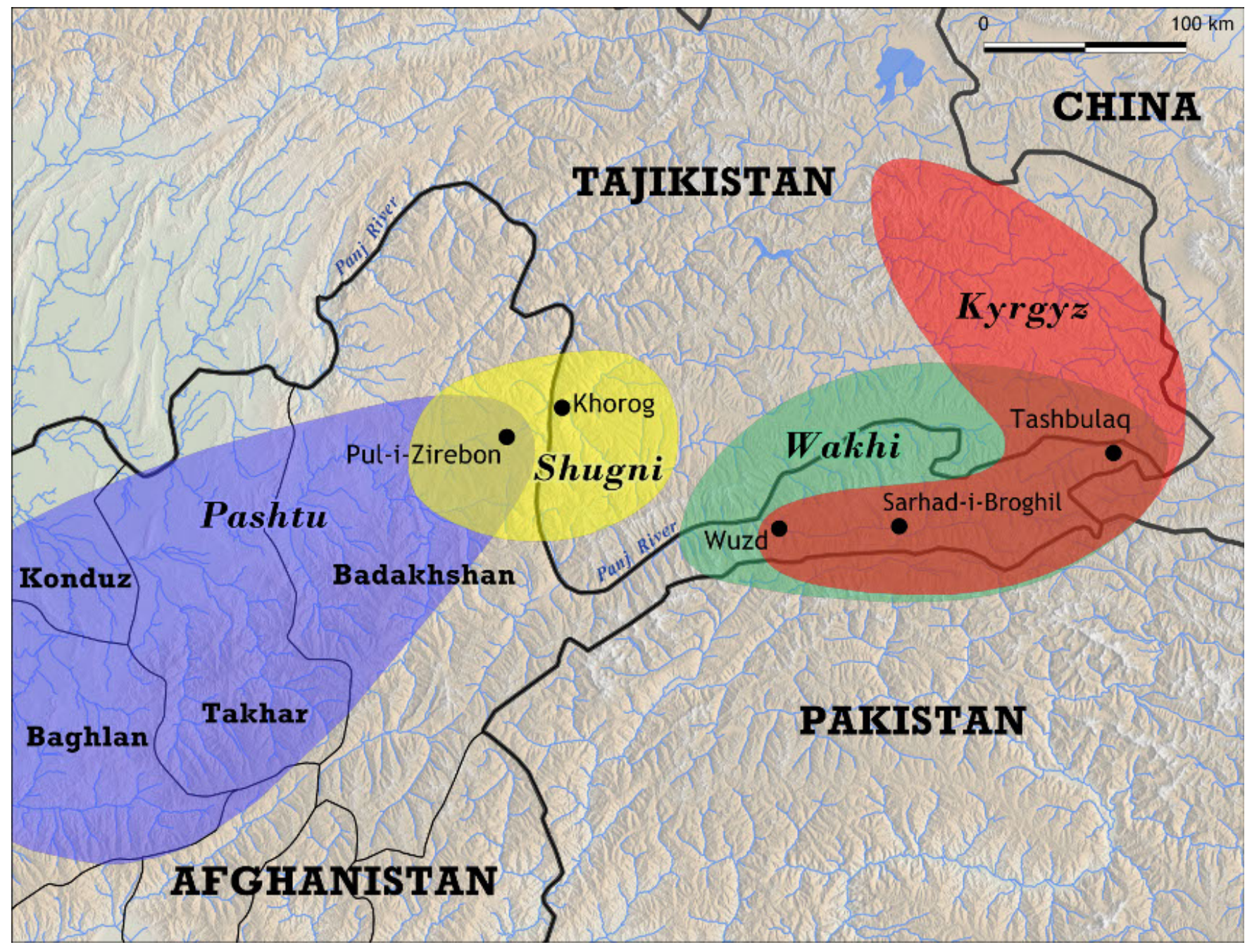

that do not have sufficient grain for the entire year must decide between saving their store of grain for seeding in the next season or consuming it to meet their immediate needs for food. To supplement their diet, mountain villagers often resort to making soup out of a plant called chazg in Wakhi and thirich in Shugni (possibly Sisymbrium brassiciforme), although extended use of this plant causes fatigue. (I have heard villagers in the Wakhan, Shugan, and Rushan regions of Afghanistan refer to this plant since 2006, and Felmy and Kreutzmann (2004) also referred to the deleterious effects of its long-term use.) The Kyrgyz, another ethnic group, are largely nomadic pastoralists located in high pastures valued for spring and summer grazing of their animalsmostly sheep and goats (because they are highly marketable), yaks (for local consumption and transport), and horses, donkeys, and camels (for transport of supplies). The mobility of the Kyrgyz optimizes the ecosystem services they draw upon. Long periods of high-altitude grazing in spring and summer, combined with shorter grazing periods in low-lying areas in winter, enable the Kyrgyz to use natural resources in dispersed locations. The Wakhi use mixed farming and mountain agriculture to produce fodder for their herds to consume in winter, but in summer they also use high mountain plateaus as pastures. Proximity of pasture lands and overlap 
of land use in the spring and summer requires an understanding between the two communities for sharing common resources. In short, each of the two communities occupies a distinct ecological niche, but the two niches overlap seasonally.

Diversity in this region is complex; it exists not only at the level of ecological habitat, in terms of livelihood and ethnicity, but also in language and religion. Linguistically, Wakhi is related to Iranian languages of the Indo-European family, while Kyrgyz is related to Turkic languages of the Altaic family. The Kyrgyz are Sunni Muslims and the Wakhi are Shia Ismaili Muslims. Kyrgyz and Wakhi habitation in the Wakhan corridor of the Pamir was not a free choice but occurred through a historical process of various groups competing for strategic control of resources. Over time, the Wakhi as Shia Ismaili Muslims have faced persecution at the hands of various Sunni groups who have invaded and occupied the region, while the Kyrgyz underwent a similar process of marginalization at the hands of the Mongols, and more recently, the nation state. Historically, according to Shahrani (1979), the Kyrgyz have experimented by moving from nomadism to sedentary agriculture back to nomadism as they sought to adapt to changing political authority. The Great Game, begun with the colonial aspirations of Britain and Russia and continued with the imperial machinations of the West and the Soviet Block (Kassam 2009b), gave impetus to the "closed frontiers" mentioned by Shahrani, which limited movement and trade along the Silk Road. Given the context of long-term warfare, hegemony of a narrow interpretation of Sunni Islam under the Taliban, limited arable land in mountainous regions, and religious and ethnic differences, one might expect that this part of the Pamirs would be ripe for conflict. However, it is precisely this diversity that enables these two communities to engage in close relations that ensure each other's survival.

The Wakhi grow wheat and barley, which they trade with the Kyrgyz. They also mill the grain into flour for the Kyrgyz. The Kyrgyz, for their part, respect the pasture lands of the Wakhi and trade animals with them in return for milled grain. The Kyrgyz also trade rope, hide, and other items manufactured from their herds. The Wakhi also obtain tea, salt, oil, and other items from the south and occasionally act as middlemen for the Kyrgyz (Fig. 4). The Kyrgyz employ poorer members of Wakhi households to tend to their livestock, and pay them with animals. Some Wakhi from Sarhad-i-Broghil give their yaks and occasionally camels to the Kyrgyz for care in the winter season. For the care of 10 yaks, the Kyrgyz may take a one-year-old yak in payment. These interchanges generate strong relations between neighbors.

Unlike observations from other studies (Shahrani 1979: 192), these findings indicate the Wakhi and Kyrgyz do not show mutual contempt based on religious differences. By using specialization of ecological niches, these two different Muslim cultures ensure resilience and the common good while simultaneously acknowledging differences. When they are in each other's territory, hospitality is extended, and they live at each other's homes while securing supplies and engaging in trade. The Kyrgyz and Wakhi who are regularly in contact can communicate in each other's languages. The plurality of difference in terms of religious, cultural, and ecological niche is respected and seen as an asset. Some Wakhi have Kyrgyz names because they were born in or near Kyrgyz pastures. Moreover, the two groups also share religious shrines, each drawing inspiration and comfort from its own interpretation of Islam. While the Kyrgyz are Sunni, they have historically faced persecution for not being orthodox enough. The Wakhi Ismailis, who as Shia have historically been targeted as heretics, generally resist the fundamentalist and literalist impulse (Bliss 2006). These groups have used their ecological context, as well as religious and cultural diversity, to resist the external homogenizing tendencies of narrower interpretations of Islam through mutual interdependence and generally peaceful coexistence.

\section{The human ecology of the Pashtu and Shugni}

Like the Kyrgyz and Wakhi, the Arab Pashtu and the Shugni in Afghanistan have a complex and symbiotic relationship. The Arab Pashtu are pastoralists. They migrate in the spring from lowlands in the provinces of Baghlan, Konduz, and Takhar to the highlands near Pul-i-Zirebon, in the province of Badakhshan. Since both humans and livestock depend on salt, villagers from Badakhshan have historically traveled to lowland markets such as Faizabad to purchase it (Barfield 1981). The Arab Pashtu are Sunni Muslims and speak Dari, an IndoEuropean language related to Persian. The Shugni 
Fig. 3. Kyrgyz settlement of Tashbulaq and Wakhi village of Sarhad-i-Broghil.

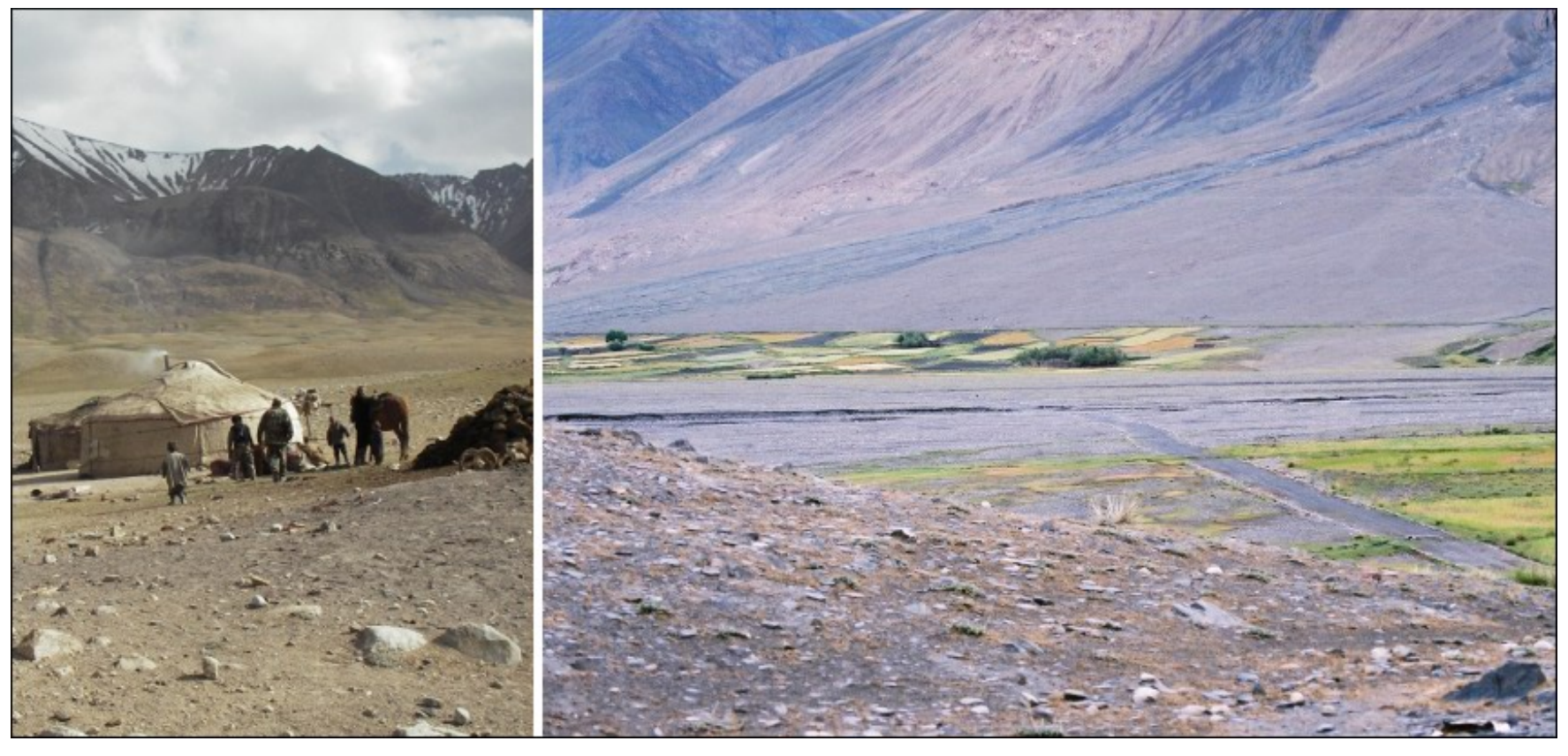

are highland farmers who live in the region of Puli-Zirebon near Lake Shiva, Badakhshan. The Shugni also have animals, and in the summer, Pashtu encampments and pastures border their villages and pasture lands. The Shugni are Ismaili Muslims and speak Shugni (like Wakhi, an IndoEuropean language of the Pamir group). Like the Kyrgyz and Wakhi, the Pashtu and Shugni who have regular contact can speak each other's languages.

The professions of these ethnically and religiously diverse groups are distinct, but seasonally their habitats overlap. The Arab Pashtu arrive in Badakhshan in June and return to the south in September, traveling three weeks to a month in each direction. It is noteworthy that the Pashtu consider themselves the wealthier members of the relationship. The measure of their wealth is the number of animals: while the Pashtu nomad is said to have 800 to 1000 sheep and goats, a Shugni farmer is considered wealthy if he has 50 animals. The Pashtu openly acknowledge the relative poverty of their Shugni neighbors: "We do not fight with them [the Shugni] because they are so poor. Instead, we consider them our brothers." Equally, the Shugni acknowledge the relative wealth of their nomadic trading partners.
The Shugni grow mainly wheat, barley, and peas and keep livestock such as goats, sheep, and a few cattle, as well as horses and donkeys. When they have surplus crops, the Shugni are unable to move these commodities to the lucrative southern markets. While the Arab Pashtu carry sufficient rice on their animals during their migration to the highlands of Badakhshan, they buy their wheat, as well as dried yogurt, from the Shugni. The Arab Pashtu are an important (albeit seasonal) force in Badakhshan because they are the link between the lowlands of the south and the highlands of the north. The difference between these ecological zones works to their advantage in trade and facilitates a symbiotic relationship with the Shugni farmers in Badakhshan. The relationship has been mutually beneficial. The Shugni obtain tea, salt, oil, ironware, cloth, and kitchenware from the Pashtu, and sometimes donkeys, cows, sheep, and goats. Most of the time, items are exchanged and not purchased using cash. The subsistence agriculture of the Shugni does not provide the villagers in Badakhshan with sufficient cash to purchase salt, tea, cloth, and ironware from distant markets, and they must make long journeys to Faizabad and Rustaq to obtain necessary goods. Aware of the cash needs of villagers, the Pashtu bring sufficient cash to the 
Fig. 4. After completing trading transactions: Kyrgyz guests at the home of Chaqanboy in the Wakhi village of Sarhad-i-Broghil.

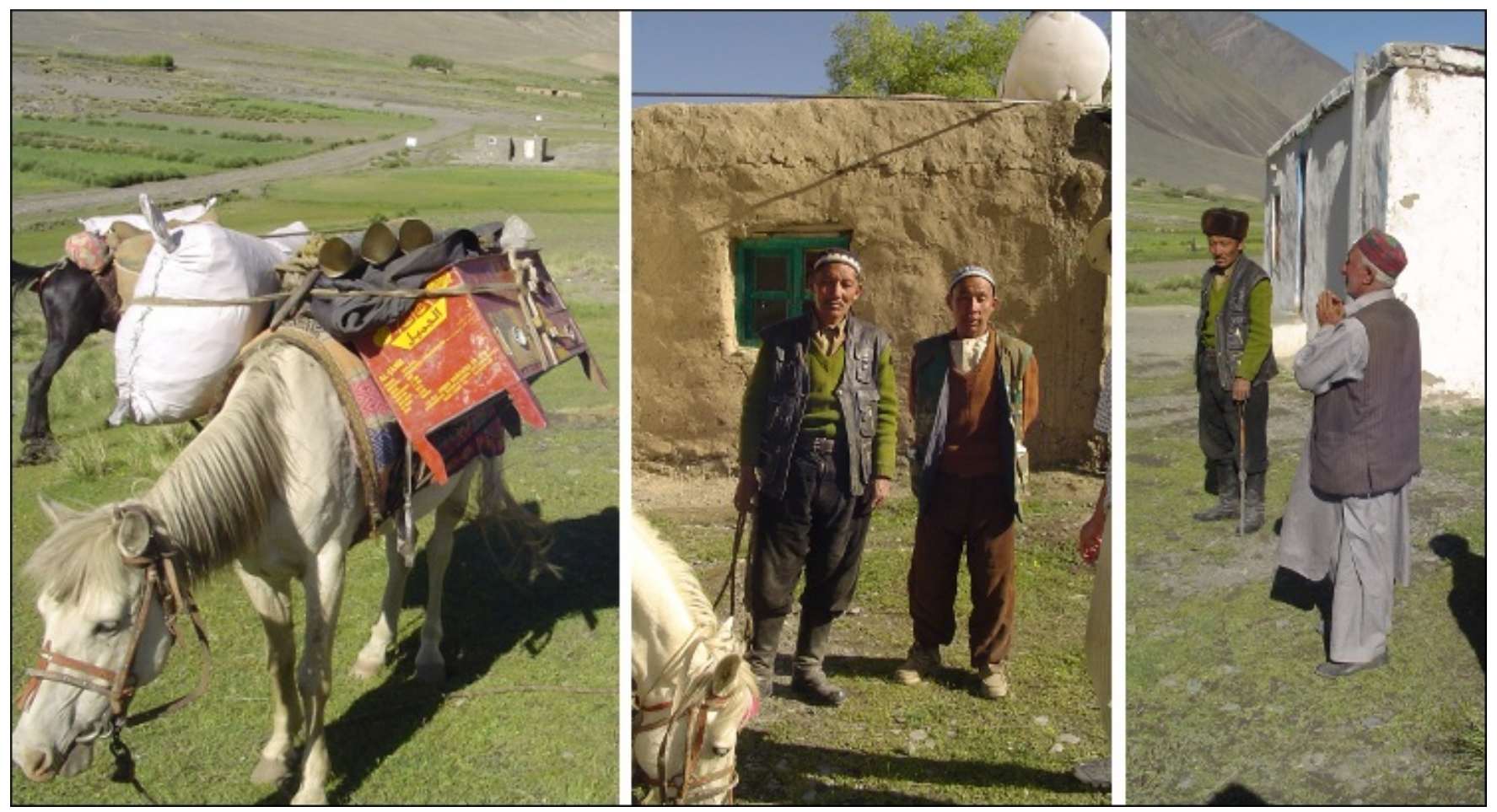

highlands to purchase wheat from the Shugni (Barfield 1981).

These transactions, which take place between individuals (generally men), are based on relations established between the Shugni and the Arab Pashtu. During the interviews, both villagers and nomads reported sustaining relations that were first established by their grandfathers more than 40 years ago. We observed Arab Pashtu arriving in the village with their camel, horse, or donkey, having tea at the Mamon Khana (guest house), meeting their friend in the village, securing the wheat they required, having the wheat milled into flour, and sometimes spending the night at the home of their Shugni host, and then returning to their encampment. In 2008, dry weather and shortage of rain resulted in a poor harvest. The cold winter and greater snowfall in 2009 exacerbated the food problem, as supply roads were closed. Conservative estimates indicate that 66 people died of severe malnutrition: 57 children, seven pregnant women who died while giving birth (newborns did not survive either), a 75-year-old man, and a 60-year-old woman. As the villagers were receiving emergency food aid, the Pashtu nomads arrived to purchase wheat. It is clear that some villagers traded the emergency supplies for cash needed to buy other necessary items. As a result of these relations, a villager may ask his nomad friend to bring a list of items from southern markets, such as cloth and kitchenware, on his next trip north. When the Shugni go south, the Pashtu extend similar hospitality. While Shugni women do not visit the homes of the Pashtu in the lowlands, the Pashtu women do visit the homes of the Shugni women when in the highlands. In the villages, the nomad not only has an assured place to sleep, but experiences the stability of long-term hospitable relations.

As noted earlier, the Shugni farmers also keep animals, using mountain pastures in the summer. However, as they lack the resources to retain a large group of animals through the harsh winter, the 
Shugni trade their goats and sheep to the Arab nomads. The Pashtu nomads can pay cash or exchange the expensive items they have transported from southern markets for goats and sheep to renew or increase the size of their herds. This trade saves the Shugni farmers a major trip to the market.

During summer, wealthier Shugni (who have more than 50 animals) give some of their male goats and sheep to the Pashtu to tend in their pastures. In the autumn on their return to south, the Pashtu return the animals to the Shugni. Similarly, during their stay in the highlands, the Pashtu bring their injured animals to the Shugni to tend in the vicinity of their villages. In the winter season, the Shugni give their male horses and bulls to the Pashtu to take south, and in the spring they bring them back. The Pashtu also store their extra supplies, such as tea and salt, in the homes of Shugni.

The Shugni maintain that conflict with their Pashtu neighbors is rare but may arise when the Pashtu shepherds are careless and let their animals graze in Shugni pastures, crop land, or land designated for growing fodder. Although the niches overlap, the presence of spatial boundaries speaks to the old adage that "good fences make good neighbors". The Shugni also pointed out that conflicts are usually resolved in favor of the side that possess the most resources to influence decisions made by local government arbiters. Both the Shugni and the Pashtu are at the mercy of regional government commanders who are extorting animals from the two communities. These local commanders are particularly vicious to the Pashtu (who have relatively more wealth to extort). Use of pastures in Badakhshan is highly competitive, and access to new pastures is acquired through purchase, rental, or theft (Fig. 5). Pasture rights were established and reorganized in 1921 by Nadir Khan. The Arabs have exclusive rights to pastures in the form of firmans (deeds) issued by the government. These rightswhich are not tribal or common property, but individual family rights - are guaranteed by the state, and they may be bought, sold, rented, or inherited. While the Arab Pashtu have individual titles to summer pasture use, the Shugni villages have collective title to their traditional summer pastures. The idea of renting pastures reinforces the notion of private ownership (Barfield 1981). In our interviews, the Pashtu reported increasing difficulties with local government because their lands are under threat from local commanders. In the highlands, these commanders buy up from the government the pasture land on which the Pashtu have traditionally grazed their animals. They then rent it back to the herders for 4000 to 5000 Afghani (US\$80 to \$100) per season, a significant capital outlay in this region. In many cases, the Pashtu have deeds to prove grazing rights from the time of their grandfathers, but the local commanders insist that they pay to use the land. And in the spring, as the Pashtu migrate northward with their animals from lowland provinces such as Baghlan, Konduz, and Takhar, these local commanders control the trails and demand animals in return for safe passage. When the Pashtu tribesmen refuse, the commanders or their henchmen beat the tribesmen and take their animals by force. These chronic external stressors may have the cumulative effect of reducing the capacity for resilience of both the Arab Pashtu and the Shugni by introducing the threat of violence and conflict.

Like the Kyrgyz and Wakhi, the Pashtu and Shugni do not practice intermarriage, thereby retaining their cultural distinctiveness. However, Shugni women recalled past times when their families were indebted to the wealthier Pashtu tribesmen, and women were given to repay the debt. "In earlier days, our ancestors were very dependent on Pashtu because they were prosperous, and our ancestors were always in debt, which they could not repay, but they would give away their daughter in return for the debt. Now there are no such cases, and may God prevent their return." The giving of daughters as repayment of debt is no longer practiced. Barfield (1981) reported that sometimes close ties between wealthy Shugni farmers and Pashtu nomads are secured by a one-way marriage relationship between Shugni women and Arab Pashtu men. He maintained that Arab Pashtu refuse to let their women marry Shugni men. However, our interviews indicate that, in fact, both sides reported no marital connections.

Unlike the Wakhi and Kyrgyz, the Pashtu and Shugni do not share Mazars (sacred places). "We do not say bad things about their [Shugni] Jamat Khanas (places of prayer) and we do not visit them, and they do not say bad things about our holy places and they do not visit them. Moses had his religion and Jesus had his religion." The Ismaili Muslims, in their places of worship, pray with both genders present, men on one side and women on the other. There is no physical barrier, and both genders are given equal preference of space as both equally 
Fig. 5. Bruises on the arm of an Arab Pashtu herder.

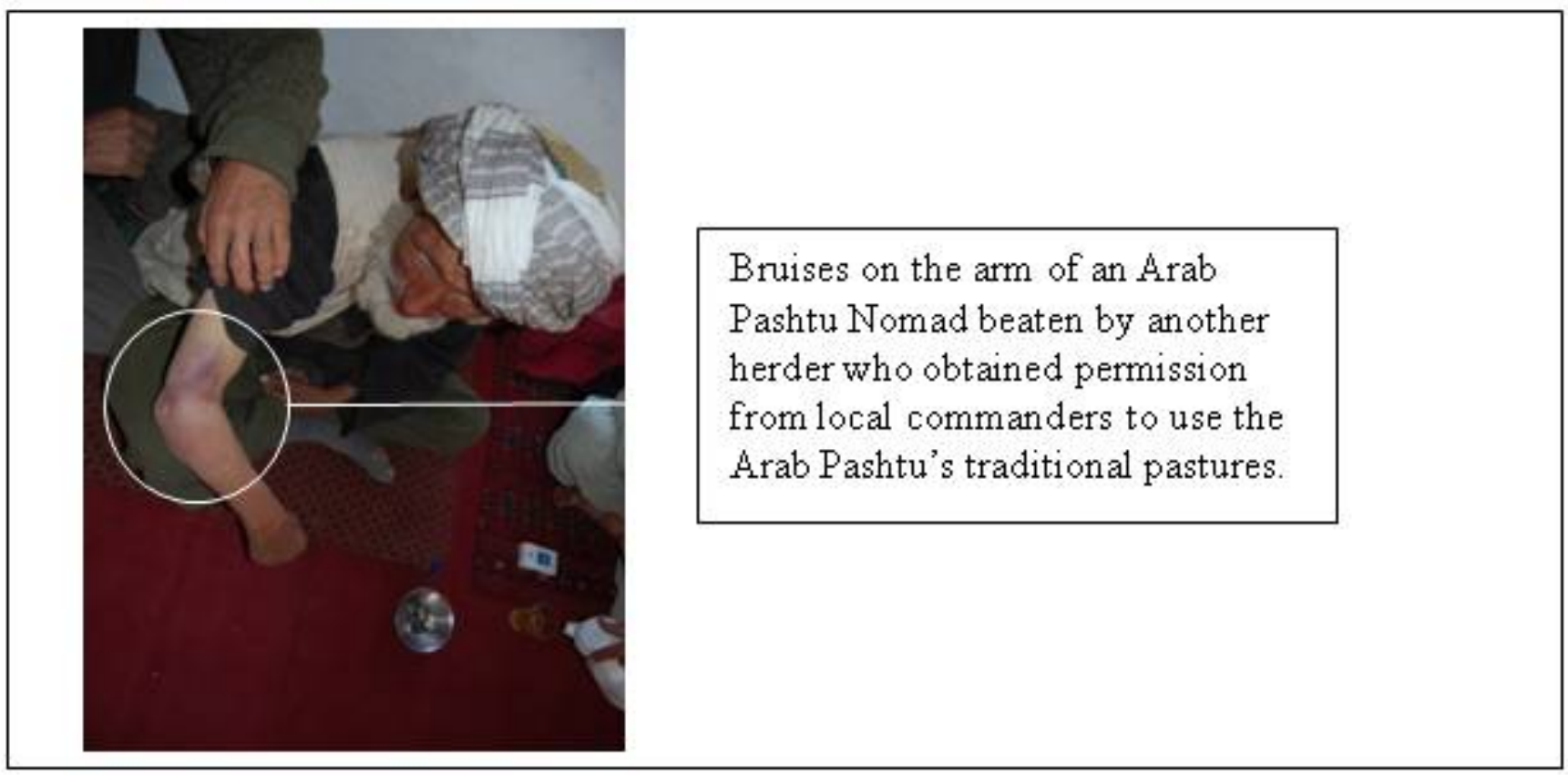

occupy the space of the prayer hall from front to back. During the summer, while the Pashtu were visiting the village of Pul-i-Zirebon, women did not attend the Jamat Khana for prayer. The Shugni men explained that they were absent to protect themselves from persecution by followers of the more extreme interpretations of Islam.

The nomads also help their Shugni friends secure winter employment in the southern lowlands. The less wealthy Shugni seek seasonal employment in the south, and at this time, they live at the homes of their Pashtu friends. Their work tends to involve caring for and feeding livestock, collecting fuel for heating the Pashtu homes, and fetching water. They may also work as agricultural laborers, plowing fields in the lowlands and planting rice. They are paid in cash, and payment is mutually decided before they come south to work. Such seasonal employment lasts for one or two months.

\section{DISCUSSION}

I suggest that both the human ecology of the Kyrgyz and Wakhi who live in the Wakhan corridor and the seasonal interaction between the Pashtu and Shugni in Badakhshan, Afghanistan practice pluralism through the complex connectivity of ecological and socio-cultural relations (See Table 1: Comparative Summary). Furthermore, this pluralism, facilitated by niche complementarity, has been the basis of resilience for these two pairs of communities under conditions of political and economic instability and war. I first discuss analogues of these case studies in other indigenous cultures and mountain societies, and examine facilitative relations, like the ones found between the Kyrgyz and Wakhi or the Pashtu and Shugni, in other ecological interactions, such as those in plant communities. Subsequently, the notions of pluralism and resilience are considered with respect to the two case studies outlined above. 
Table 1. Comparative summary of two case studies (Kyrgyz and Wakhi, Arab Pashtu and Shugni).

\begin{tabular}{|c|c|c|c|c|c|}
\hline & Kyrgyz & Wakhi & Arab Pashtu & Shugni & Comparison \\
\hline Religion & Sunni & Shia Ismaili & Sunni & Shia Ismaili & Religious distinctiveness \\
\hline Language & Kyrgyz & Wakhi & Dari & Shugni & Cultural distinctiveness \\
\hline Profession & $\begin{array}{l}\text { nomadic } \\
\text { pastoralists }\end{array}$ & $\begin{array}{l}\text { sedentary } \\
\text { farmers with } \\
\text { livestock }\end{array}$ & $\begin{array}{l}\text { nomadic } \\
\text { pastoralists with } \\
\text { some } \\
\text { agricultural land }\end{array}$ & $\begin{array}{l}\text { sedentary } \\
\text { farmers with } \\
\text { livestock }\end{array}$ & $\begin{array}{l}\text { In both cases, Sunni Muslims are } \\
\text { pastoralists, while Ismaili Muslims } \\
\text { are sedentary farmers who keep } \\
\text { animals. }\end{array}$ \\
\hline $\begin{array}{l}\text { Trade } \\
\text { items }\end{array}$ & $\begin{array}{l}\text { goats, sheep, } \\
\text { yaks, and other } \\
\text { livestock, and } \\
\text { manufactured } \\
\text { items such as } \\
\text { rope and hide } \\
\text { produced from } \\
\text { their herds }\end{array}$ & $\begin{array}{l}\text { wheat, } \\
\text { occasionally } \\
\text { items from } \\
\text { southern markets } \\
\text { such as salt, tea, } \\
\text { and oil }\end{array}$ & $\begin{array}{l}\text { livestock, } \\
\text { kitchenware, } \\
\text { ironware, salt } \\
\text { and other items } \\
\text { from southern } \\
\text { markets, cash }\end{array}$ & $\begin{array}{l}\text { wheat, animals, } \\
\text { dried yogurt }\end{array}$ & $\begin{array}{l}\text { In the case of the Kyrgyz and } \\
\text { Wakhi, both nomads and farmers } \\
\text { have items from southern markets to } \\
\text { trade. In the case of the Pashtu and } \\
\text { Shugni, the pastoralists bring } \\
\text { southern market items to trade for } \\
\text { agricultural items. }\end{array}$ \\
\hline Employment & employer & employee & employer & employee & $\begin{array}{l}\text { In both cases, pastoralists are } \\
\text { employers. }\end{array}$ \\
\hline $\begin{array}{l}\text { Habitat } \\
\text { (Location) }\end{array}$ & $\begin{array}{l}\text { Highlands: } \\
\text { nomadic use of } \\
\text { seasonal high- } \\
\text { elevation } \\
\text { mountain } \\
\text { pastures and } \\
\text { valleys }\end{array}$ & $\begin{array}{l}\text { Highlands: } \\
\text { valleys and } \\
\text { villages of } \\
\text { Sarhad-i-Brogil } \\
\text { and Wuzd with } \\
\text { and seasonal use } \\
\text { of high mountain } \\
\text { pastures }\end{array}$ & $\begin{array}{l}\text { Lowlands to } \\
\text { highlands: } \\
\text { valleys and } \\
\text { villages in } \\
\text { Baghlan, } \\
\text { Kunduz, and } \\
\text { Takhar with } \\
\text { seasonal use of } \\
\text { high mountain } \\
\text { pastures }\end{array}$ & $\begin{array}{l}\text { Highlands: } \\
\text { valleys and } \\
\text { village region of } \\
\text { Pul-i-Zirabon } \\
\text { with and } \\
\text { seasonal use of } \\
\text { high mountain } \\
\text { pastures }\end{array}$ & $\begin{array}{l}\text { Seasonal overlap in niche occurs } \\
\text { between the Kyrgyz and Wakhi, as } \\
\text { well as between the Pashtu and } \\
\text { Shugni. }\end{array}$ \\
\hline Elevation & $3500-4000 \mathrm{~m}$ & $2500-4000 \mathrm{~m}$ & $500-4000 \mathrm{~m}$ & $2500-4000 \mathrm{~m}$ & $\begin{array}{l}\text { In the case of Kyrgyz and Wakhi, } \\
\text { pastoralists are at higher elevations. } \\
\text { In the case of Pashtu and Shugni, the } \\
\text { pastoralists are at lower elevations. }\end{array}$ \\
\hline $\begin{array}{l}\text { Sacred } \\
\text { sites }\end{array}$ & shared & shared & not shared & not shared & $\begin{array}{l}\text { Both cases demonstrate diversity in } \\
\text { religious distinctiveness. }\end{array}$ \\
\hline
\end{tabular}




\section{Conceptual moorings in niche complementarity}

Niche complementarity emerges from interspecific differences in resource requirements and in spatial and temporal resource and habitat use. Furthermore, niche complementarity resulting from positive interactions enables stable coexistence of many species and predicts greater productivity at higher levels of diversity. For instance, niche complementarity "increases with diversity because no monoculture is as productive as some combination of two species, and no combination of $\mathrm{N}$ species is as productive as some combinations of $\mathrm{N}+1$ species" (Tilman et al. 2001: 843). At the core is the idea that a community of species whose niches complement one another is more efficient in its use of resources than an equivalent set of monocultures. Therefore, niche complementarity may explain why higher diversity tends to lead to higher productivity, and arguably it may suggest that more efficient communities would fare better in the face of stress (Naeem 2002). In the case of the Wakhi and Kyrgyz or the Pashtu and Shugni, productivity is primarily survival and food security (Figs. 6A and 6B illustrate the seasonal overlap of ecological niches between the Kyrgyz and Wakhi and the Pashtu and Shugni, respectively). It is an illustration of niche complementarity that extends beyond discussion of diversity at the level of religion and ethnicity on the one hand, and beyond discussion of habitat just in terms of species on the other. In short, the idea of ecological niche includes culture, religion, ethnicity, lifestyle, and habitat.

Barth (1956) applied the concept of ecological niche in the Swat region of Northern Pakistan. His findings indicated that the environment of an ethnic group is defined not only by the physical context, such as ecological services, but also by the presence and activities of other ethnic groups. While useful, Barth's conclusions do not fully reflect the organic interaction of religious, ethnic, and ecological aspects. One conclusion is that "if different ethnic groups are able to exploit the same niches fully, the militarily more powerful will normally replace the weaker" (Barth 1956: 1088). The current engagement between the Kyrghyz and Wakhi or the Arab Pashtu and Shugni is not related to military strength, but concerns access to economic resources. The Kyrgyz and Pashtu (who are nomads) have greater economic resources, but they continue to be dependent on the Wakhi and Shugni (farmers who also use high pastures).
The multiplicity of ecological environments in the Pamir Mountains is advantageous for ecosystem services in general and food security in particular. Murra, in his work on Andean societies before Pizarro's invasion in 1532, similarly illustrates that ecological complementarity, rather than being an inhibiting factor, not only maintained ethnic selfawareness but also facilitated food sovereignty among diverse cultural communities in that mountainous area (Murra 1985a). Unlike food security, which suggests access to food, food sovereignty encompasses the ability of groups to choose their own food based on preferences determined by socio-cultural and ecological systems they inhabit (Mousseau 2005, Windfuhr and Jonsén 2005). As a result, different ethnic groups shared and exchanged mountain resources (both high-mountain and low-valley products) across ecozones through reciprocity and kinship ties, while each group maintained its own ecological niche (Murra 1985b). While not duplicating the model of Andean societies described by Murra, the Kyrgyz and Wakhi do not just engage in trade, but have relations involving reciprocal use of human energies. For example, the Wakhi work for the Kyrgyz in the summer pastures in order to increase their own livestock holdings.

According to Murra, a mountainous environment is highly variable on a short-distance scale, where the main factor is elevation. Therefore, the landscape can be envisioned as a series of steps, or tiers, of ecological niches, with different resources available in each. Furthermore, the steepness of the mountainous region means that the ecological edges may be close together, overlapping different ecological niches and crossing different ecological zones, where different climates and resources are found. The Arab Pashtu have used movement through differing cultural and ecological zones to secure their food sovereignty by developing ties with the religiously, ecologically, and ethnically distinct Shugni.

Turner et al. (2003) support Murra's view of overlapping ecological zones, arguing that ecosystem edges (the transition zones between different ecosystems), are characterized by high biodiversity. Furthermore, when cultural transition areas converge with these ecozones, they too exhibit cultural richness. Therefore, at times of stress, these ecosystem edges provide indigenous communities with a means of enhancing resilience through flexibility and adaptive capacity. These ecological edges, along with their resources, facilitate trade and 
Fig. 6. Seasonal overlap of ecological niches of (A) the Kyrgyz and Wakhi and (B) the Pashtu and Shugni.

A.

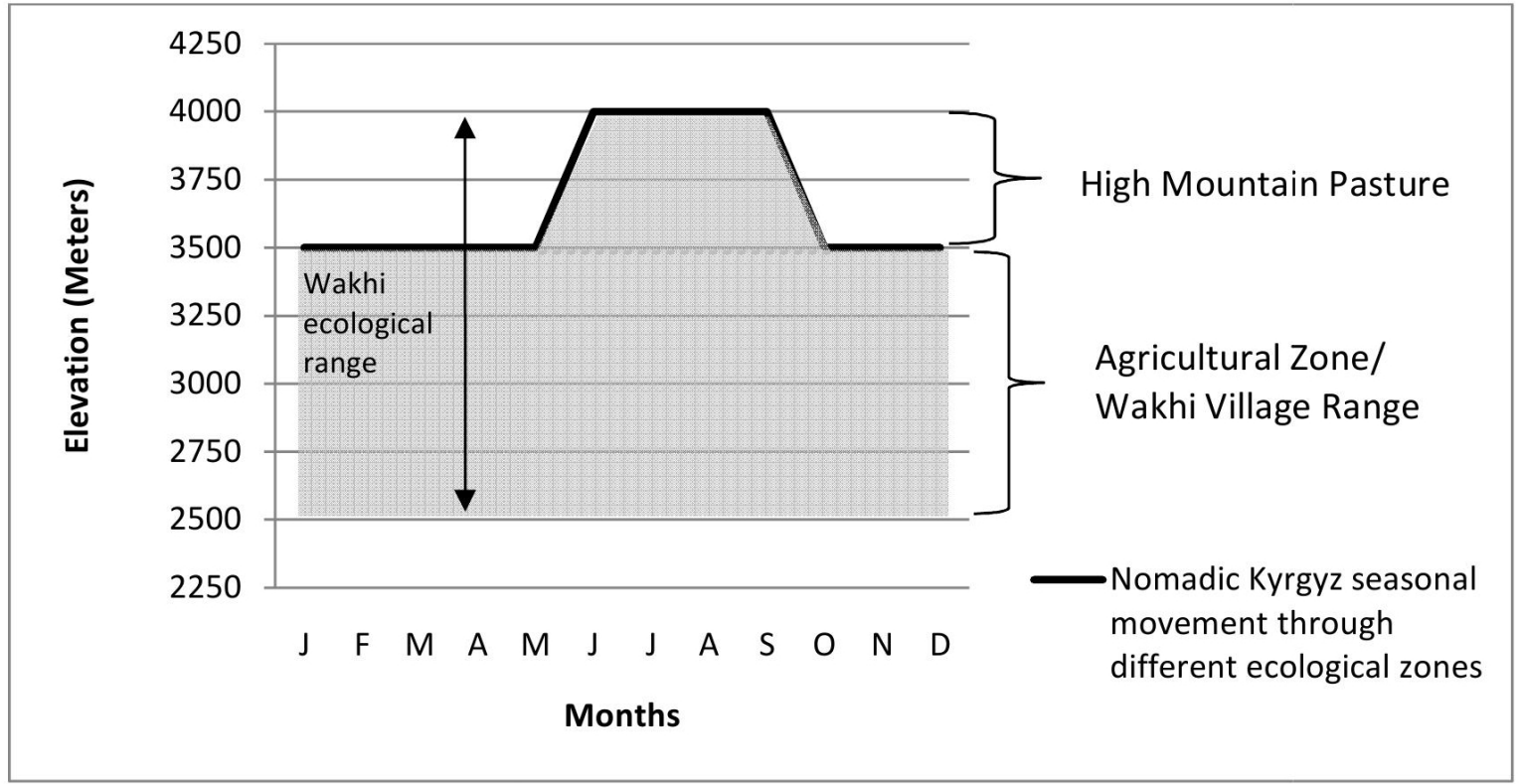

B.

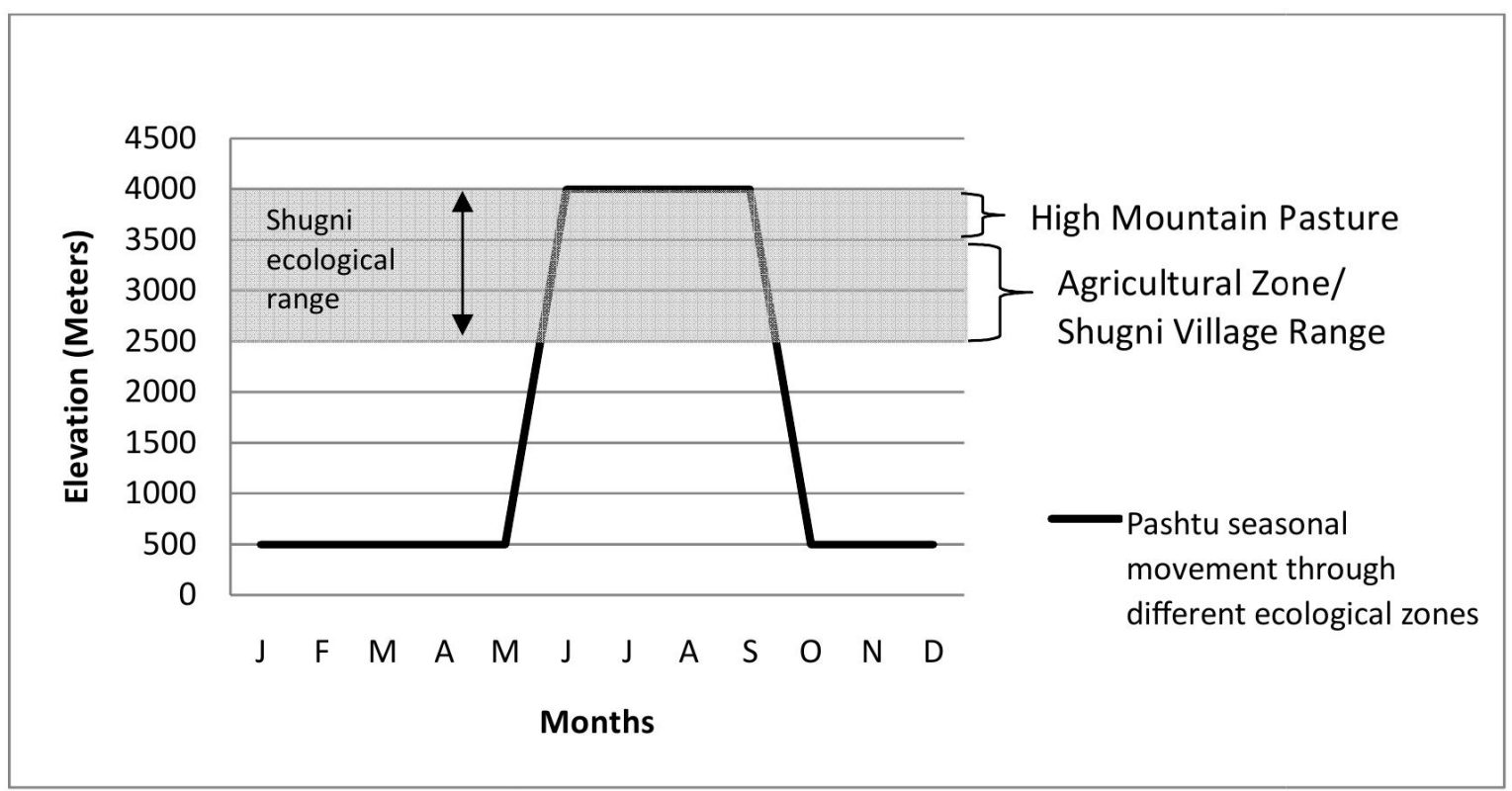


exchange between different cultural groups. What is noteworthy about the Turner et al. (2003) case studies of indigenous communities in Canada is that these groups not only traded food items such as dried fish or berries and manufactured products such as baskets, but they also exchanged knowledge and ideas. Their cultural distinctiveness was retained during trade and facilitated the exchange. They discussed fishing, hunting, canoe-making, and basket-making techniques. As a result of these consistent, long-term exchanges, the relations between these groups have become institutionalized. Thus, communities from different ecological habitats and lifestyles mutually support and facilitate each other's survival. Their contact is not just trade in widgets, but exchange of ideas and strategies that facilitate flexibility and resilience in the context of unanticipated change and significant socio-economic stress.

The examples of Murra (1985a, 1985b) and Turner et al. (2003) illustrate that trade involved coupled socio-cultural and ecological systems. In the Kyrgyz and Wakhi and Pashtu and Shugni cases, cultural distinctiveness arising from religious and ethnic diversity enhances relations and facilitates exchange. In turn, mutual support through exchange supports cultural distinctiveness. In this sense, cultural distinctiveness is retained not only through the absence of intermarriage, the practice of a different interpretation of Islam, or speaking a different language, but at the level of ecological lifestyle, namely the professions of farmer and nomad. This distinctiveness is also made complex by overlap: the Shugni and Wakhi may be farmers, but they also keep animals in summer pastures like the Pashtu and Kyrgyz. This overlap is supported by facilitative behavior that is largely absent of conflict in the face of external obstacles such as environmental change, economic marginalization, and war.

Examples of such facilitative behaviors are also found in ecological literature on relations in plant communities. Callaway and Walker (1997), who examined interactions in plant communities, argue that these interactions are complex and scientists have been limited by studying mostly solitary phenomena. Both direct and indirect interactions contribute to competition and facilitation in communities. Plant communities under abiotic stress seem to tend toward facilitation. Do such explanations also apply to human communities with different habitats whose ecological niches overlap? Humans, like other creatures in their habitat, are biological beings; like plant communities, they demonstrate facilitative behavior. Just as plant communities require context-specific conditions for facilitative or positive relationships to occur, human communities depend upon context-specific relations involving ecological profession, cultural values, and institutions. Therefore, as positive relationships that are less individualistic contribute to coevolution in plant communities (Callaway 1998), similar facilitative relations among the Kyrgyz and Wakhi or the Pashtu and Shugni have the consequence of contributing to mutual survival and food security.

\section{Pluralism as an organic outgrowth of socio- cultural and ecological diversity}

Pluralism acknowledges diversity in the natural environment and human culture. With respect to the changing world of sensory experience, pluralism rejects monism and dualism. It eschews a conception of reality that reduces nature to a single basic principle. Therefore, it rejects absolutist, monolithic, unitary explanations. Furthermore, it accepts that change is a normal part of socio-cultural and ecological processes. Through recognition of both diversity and change, pluralism as a concept asserts that diverse groups can work successfully to realize the common good for society as a whole (Kallen 1915, Engelhardt and Jennings 1989, Mason 2006).

The notion of pluralism goes beyond the idea of socio-cultural and ecological diversity as empirical fact; it means valuing this diversity and deeming it worthy of conservation as a normative objective. Pluralism embodies relations across differences. It involves recognizing the integrity of other groups and valuing their distinctiveness and independence. The focus of pluralism is relations and the evolution of patterns of relations between groups (Schlosberg 1999). Patterns of relations between the Kyrgyz and Wakhi as well as the Arab Pashtu and Shugni demonstrate interdependence with flows of material and non-material resources. Furthermore, these relations span ecological boundaries. While pluralism goes beyond the mere functional role of diversity, it is firmly grounded in an organic engagement between the socio-cultural and ecological. 
In spite of and because of the differences, one group's acceptance of the other group's right to exist within the same ecological space is what makes the relations between the Kyrgyz and Wakhi and the Arab Pashtu and Shugni noteworthy in the context of Afghanistan. The concept of pluralism infuses hope because it demands that we envision human societies not as victims but as agents. This agency arises from the ability of diverse groups to affect the social fabric of their respective communities in order to adapt to change and achieve the common good. For pluralism to be effective in achieving the common good, diverse groups must agree on some basic values, share some interests, and develop rules for conflict resolution (Galston 1989, Langerak 1994, Axelby 2007). Both the Kyrgyz and Wakhi case and the Pashtu and Shugni case illustrate that pluralism has many facets, not only socio-cultural interactions, but also human ecological relations. In this sense, the common good is achieved by harnessing ethnic, religious, and ecological diversity.

The case of the Kyrgyz and Wakhi or the Pashtu and Shugni is informative because their milieu is rife with conflict, yet their approach is pragmatic as they negotiate human-ecological relations that help secure their livelihoods through the practice of pluralism. The interdependence between the Kyrgyz and Wakhi or the Pashtu and Shugni is not limited to economic self-interest. This interdependence is not only an outcome of a materially determined calculus, but an organic engagement of diverse cultural systems and social structures in the context of varied but overlapping ecological zones. Trust and confidence sustain this interdependence (Smith 1976). It is noteworthy that the notions of "diversity" and "pluralism" are part of the lexicon among the ethnically varied Muslims in the Pamir Mountains of Central Asia. A geological crosssection of religious history in the Pamir Mountains reveals the presence and ongoing influence of indigenous beliefs, Zoroastrianism, Buddhism, and multiple interpretations of Islam. Instead of weakening the foundation of social life, a lack of homogeneity in the religious sediments of the people of the Pamirs contributes to a pluralistic cultural fabric that enables resilience and facilitates survival. For instance, the ethnically diverse Shia Ismaili Muslims, which include the Wakhi and Shugni as well several other groups in both Afghanistan and Tajikistan, have specific words for cultural diversity and pluralism. The use of the words chandandeshi ('several opinions') to refer to diversity and gunoguni ('varieties') to refer to pluralism, which I first noticed during interviews in 2006, emerged in the 1990s, at the time Soviet power was waning, Taliban power was growing, and outside contact was increasing (Dr. Sharofat Mamadambarova, personal communication). These words reflect the speakers' awareness of both the variety of cultural traditions found among the Ismailis globally and the different religious and ethnic groups Ismailis find in the midst of their respective habitats. Their use of these words suggests that they intellectually apprehend the notion of pluralism and make use of it practically. While these terms are related to Western conceptions of pluralism and are transmitted through the guidance of the Aga Khan (Aga Khan 2008), spiritual leader of the Shia Ismaili Muslims, these ideas could not have gained a foothold in this region of Central Asia unless there was already a fertile environment in which they could take root. The long and continuous history of the Silk Road in this region speaks to development of institutions that facilitated difference and negotiated conflicts. Despite the interruption of the Silk Road by closure of frontiers during the 19th and 20th centuries, this history is part of the consciousness of the inhabitants of the Pamirs. Furthermore, the continuing practice of sharing sacred sites (mazars) between the Kyrgyz and Wakhi, who are religiously and ethnically different and have different ecological professions, speaks to the historical nature of pluralistic relations. Conversely, the fact that the Shugni are afraid to practice their faith (which includes having women participate in prayers as equal partners) while the Pashtu nomads are within the Shugni ecological habitat speaks to the fragility of pluralistic relations. The practice of pluralism in the context of the Pamirs not only refers to economic interest, but encompasses a socio-cultural awareness that extends to ecological niche.

The role of pluralism in the broader context of Islam is relevant to this region of Central Asia. Pluralism in Islam is often discussed in terms of the relationship between Muslims and other religious communities. While this perspective dominates discussion of pluralism and Islam, the more pertinent challenge for the $21 \mathrm{st}$ century is the internal challenge Islam faces: namely, that anachronistic interpretations threaten its historical diversity. Financed by petrodollars and geopolitical interests, narrower and literalistic interpretations of Islam have been increasingly gaining currency in the context of livelihood 
instability, war, government corruption, and economic collapse. Talibanization and Wahabification are recent trends, while pluralism among Muslim societies is a historical fact. One of the best-known sociological analyses of pluralism in Muslim societies, the Muqaddimah by Ibn Khaldun, was written in the 14th century. While this work relates to the Atlas Mountains of North Africa, other historical works illustrate the presence of diversity in Islam and communities of interpretation throughout Muslim societies from Spain through Africa to Southeast Asia (Hodgson 1974, Lapidus 1990, Nanji 1996). There is a particular concentration of this diversity in mountainous regions (Gellner 1985). Arguably, when Muslims are accepting of diversity among their own communities, they are accepting of diversity in outside, non-Muslim communities. These case studies explore how communities espousing diverse interpretations of Islam in the Pamirs of Afghanistan coexist and co-evolve to achieve the common good through human ecological relations.

\section{Resilience through pluralism}

Resilience is the capacity of social and ecological systems to absorb disturbance and still retain their basic function and structure (Holling 1973, Folke et al. 2002, Walker et al. 2004, Walker and Salt, 2006, Miller et al. 2008). In this sense, resilience is closely linked to the sustainability of cultures, societies, and their respective environments. Specific elements of resilience include (1) the amount of change a system can tolerate and still retain its function; (2) the degree to which a system can self-organize in response to change for renewal; and (3) the degree to which a system can develop capacity through learning and adaptation to change (Carpenter et al. 2001, Folke et al. 2002).

At its core, resilience is about being able to adapt to a changing world. It is a response to vulnerability. Resilience is closely connected to the idea of pluralism in the sense of not only retaining the integrity of diverse elements of social and ecological systems under conditions of change, but acting to safeguard this multiplicity. Furthermore, resilience provides opportunity for innovation. These case studies begin to explore how Pamir societies develop resilience in their human ecological systems through the practice of pluralism. The research is complicated by a global war concentrated in a small region and by dramatic environmental change. Yet it is precisely these factors that make research on the relationship between pluralism and resilience relevant. The symbiotic relationship between the Kyrgyz and Wakhi, or the Pashtu and Shugni, retains the integrity of these two cultures and facilitates survival in their habitats.

Opposite of the monoculture effect is the notion that high diversity increases resilience, so that more diverse ecosystems are better able to respond to negative influences and recover faster after disturbances (Altermatt and Ebert 2008). It is relevant to Central Asia when comparing the sedentarized and agro-industrialized Kyrgyz and Wakhi of Tajikistan to the Kyrgyz and Wakhi in Afghanistan, who retained their ecological niche despite colonialism and 30 years of continued war. In the case study above, I spoke of the relations between the Kyrgyz and Wakhi of Afghanistan. However, the case of the Wakhi and Kyrgyz of Tajikistan is very different (Bliss 2006). For instance, empirical evidence of common resources like pastures indicates that permanent settlement of nomadic peoples and imposed state-owned agriculture cooperatives tended to degrade these lands to a greater extent than local and indigenous methods of land use (Ostrom et al. 1999). Furthermore, this evidence suggests that a pluralistic response based on socio-culturally relevant institutions suited to the context is effective. Therefore, the traditional model of the "rational" Homo economicus guided by narrow selfinterest is not relevant, and its monolithic application to policy may have deleterious effects (Henrich 2000, Henrich et al. 2001). The Wakhi and Kyrgyz of Afghanistan, who are limited in material resources compared to their relatives in Tajikistan, may in fact be better able to adapt to change because they retained their diverse ecological niches and religious diversity while their counterparts in the former Soviet Union were forced into the command economy over a period of several generations. These preliminary findings in the Afghan Pamir are positive; however, evolved norms of reciprocal cooperation are not sufficient to prevent overexploitation. The tragedies of the commons (Hardin 1968) are real, but not inevitable. Relevant socio-cultural institutions are necessary to monitor use of common-pool resources and enforce rules that limit their exploitation. The challenge is greater with global-scale problems such as climate change or water use across international boundaries. Scaling up an institutional organization to a global 
level increases both the complexity of the link between ecological and cultural diversity and the potential for conflict. A pluralistic social structure demands involvement of diverse ways of knowing in the analysis of complex issues while humans, with a growing sense of urgency, come to an agreement on responses to the environmental challenges they face (Ostrom et al. 1999, Ostrom 2000, Deitz et al. 2003). Furthermore, the Kyrgyz and Wakhi survival, while positive, is at a level that is fragile: political instability, caused largely by global powers or climatic change, may result in massive famine. Even resilience may have an upper limit.

\section{CONCLUSIONS AND NEXT STEPS}

This preliminary research contradicts the prevailing narrative of Central Asia as a region characterized by a clash of civilizations between the democratic West and a fossilizing and fanatical interpretation of Islam. First, it summons concrete evidence of the practice of pluralism in the Pamir Mountains of Afghanistan. Second, it maps the potential benefits of pluralism with respect to adaptation and resilience in the context of socio-ecological change. Third, it begins to analyze the structures that enable pluralism in these societies. Fourth, it seeks to realize a deeper theoretical understanding, with practical benefits, about the value of pluralism in the context of religious, cultural, and ecological diversity.

Sustaining resilient systems requires intellectual pluralism that incorporates local wisdom and knowledge of ecosystem dynamics (Folke et al. 2002). Applied research needs to be viewed in terms of participation of, and collaboration between, communities of social practice (such as elders, farmers, and pastoralists) who practice pluralism in day-to-day life and communities of inquirers (such as academics and civil society institutions) who wish to understand and apply the contributions of pluralism in order to promote sustainable livelihoods (Kassam 2009b). This research is merely a first step. Further research on rules and modes of conflict resolution needs to be undertaken.

Resilience is used as a metaphor to inspire. Through empirical understanding, it may be put to practical action. Inherently, it is neither positive nor negative but depends on the perspective or point of view. Resilience has both a temporal and a spatial scale; therefore, it can be facilitated by cross-scale subsidies. These case studies focused on Afghanistan, but further research should examine the resilience of the Kyrgyz and Wakhi in Tajikistan as well. Further research must also address the role of opium in current trade relations-not only in trade between Kyrgyz and Wakhi or Pashtu and Shugni but in dealings with southern traders from outside the region-and the implications for sustaining resilience and pluralism. Arguably, most literature on resilience views it as a desirable goal. In Afghanistan, however, poverty traps, institutional corruption, and violent structures are also remarkably resilient. In this case, resilience may not be desirable. Further research needs to explore the linkages between undesirable resilience and pluralism. Another area of research especially pertinent to Afghanistan would be to examine what happens in a context of religious, socio-cultural, and ecological diversity when one or more groups do not practice pluralism. This goes to the heart of the question: does pluralism imply acceptance of intolerance?

Quantitative indicators still need to be identified to supplement descriptive case studies and show the link between pluralism and resilience. Clear indicators need to be articulated for these questions: Who or what is being resilient, and to what pressures? What socio-cultural and ecological factors contribute to a resilient response? Therefore, there needs to be further research that examines resilience of these groups over longer periods of time and larger spatial scales to permit comparison of socio-cultural and ecological systems. More comparative work also needs to be done with similar mountain people elsewhere.

Responses to this article can be read online at:

http://www.ecologyandsociety.org/voll5/iss2/art8/responses/

\section{Acknowledgments:}

I am deeply grateful to the Kyrgyz, Arab Pashtu, Shugni, and Wakhi communities in Afghanistan that shared their information, ideas, and hospitality. This research was funded by a grant from the Christensen Fund. The University of Central Asia was a base of operations and provided logistical support. Safe passage across several border crossings was facilitated by the Aga Khan Foundation, Afghanistan, and FOCUS Humanitarian 
Assistance. I am grateful to my research assistants in the Pamirs, Mr. Umed Bulbulshoev, who was my interpreter, and Ms. Munira Karamkhudoeva, who interviewed the women participants and helped with plant names, as well as Ms. Michelle Baumflek at Cornell. Dr. Sharofat Mamadambarova shed light on the origin of terms for pluralism in the local languages. An earlier version of this paper was presented at a workshop entitled "Beyond Diversity: Re-Situating Pluralism" held at Cornell University in May 2009. Bernd Blossey, Kurt Jordan, Jim Lassoie, Jennifer Shirk, Jeffrey Wall, and George Wilkes provided valuable comments. Meaningful conversations with Timothy Fahey and Joseph Yavitt on ecological niche also informed this paper. Keith Jenkins helped develop the map of the research area (Figs. 1 and 2) for this publication. I am grateful to the anonymous reviewers and subject editor for their valuable suggestions and comments.

\section{LITERATURE CITED}

Adger, W. N., T. Hughes, C. Folke, S. R. Carpenter, and J. Rockstrom. 2005. Socialecological resilience to coastal disasters. Science $\mathbf{3 0 9}$ (5737):1036-1039.

Aga Khan IV. 2008. Where hope takes root: democracy and pluralism in an interdependent world. Douglas \& McIntyre, Vancouver, British Columbia, Canada.

Altermatt, F., and D. Ebert. 2008. Genetic diversity of Daphnia magna populations enhances resistance to parasites. Ecology Letters 11:918-928.

Axelby, R. 2007. 'It takes two hands to clap': how Gaddi shepherds in the Indian Himalayas negotiate access to grazing. Journal of Agrarian Change 7 (1):35-75.

Barfield, T. 1978. The impact of Pashtun immigration on nomadic pastoralism in northeastern Afghanistan. Pages 26-34 in J. Anderson and R. Strand, editors. Ethnic processes and intergroup relations in contemporary Afghanistan: papers presented at the Eleventh Annual Meeting of the Middle East Studies Association (New York, 1977). Afghanistan Council of the Asia Society, New York, New York, USA.
Barfield, T. 1981. The Central Asian Arabs of Afghanistan: pastoral nomadism in transition. University of Texas Press, Austin, Texas, USA.

Barth, F. 1956. Ecologic relationships of ethnic groups in Swat, North Pakistan. American Anthropologist 58(6):1079-1089.

Berkes, F., J. Colding, and C. Folke. 2003. Navigating social-ecological systems: building resilience for complexity and change. Cambridge University Press, New York, New York, USA.

Bliss, F. 2006. Social and economic change in the Pamirs, Tajikistan. Routledge, New York, New York, USA.

Callaway, R. 1998. Are positive interactions species-specific? Oikos 82(1):202-207.

Callaway, R., and L. Walker. 1997. A synthetic approach to interactions in plant communities. Ecology 78(7):1958-1965.

Carpenter, S., B. Walker, J. M. Anderies, and N. Abel. 2001. From metaphor to measurement: resilience of what to what? Ecosystems 4:765-781.

Chambers, R. 1997. Whose reality counts? Putting the first last. Intermediate Technology Publication, London, UK.

Chapin, F.S. III, G. Peterson, F. Berkes, T. Callaghan, P. Angelstam, M. Apps, C. Beier, Y. Bergeron, A. S. Crepin, K. Danell, T. Elmqvist, C. Folke, B. Forbes, N. Fresco, G. Juday, J. Niemela, A. Shvidenko, and G. Whiteman. 2004. Resilience and vulnerability of northern regions to social and environmental change. Ambio $\mathbf{3 3}$ (6):344-349.

Dietz, T., E. Ostrom, and P. C. Stern. 2003. The struggle to govern the commons. Science 302:19071912.

Engelhardt, T., and B. Jennings. 1989. Contested terrain: pluralism and the good. The Hastings Center Report 19(5):33-35.

Felmy, S., and H. Kreutzmann. 2004. Wakahn Wolusswali in Badakhshan. Observations and reflections from Afghanistan's periphery. Erdkunde 58(2):97-117. 
Folke, C. 2006. Resilience: the emergence of a perspective for social-ecological systems analyses. Global Environmental Change 16:253-267.

Folke, C., S. Carpenter, T. Elmqvist, L. Gunderson, C. S. Holling, and B. Walker. 2002. Resilience and sustainable development: building adaptive capacity in a world of transformations. Ambio 31(5):437-440.

Galston, W. A. 1989. Pluralism and social unity. Ethics 99(4):711-726.

Gellner, E. 1985. Muslim society. Cambridge University Press, Cambridge, UK.

Greenwood, D. J., and M. Levin. 1998. Introduction to action research: social research for social change. Sage Publications, London, UK.

Hardin, G. 1968. The tragedy of the commons. Science 162(3859): 1243-1248.

Harmon, D. 2002. In light of our differences: how diversity in nature and culture makes us human. Smithsonian Institution Press, Washington, D.C., USA.

Harmon, D. 2007. A bridge over the chasm: finding ways to achieve integrated natural and cultural heritage conservation. International Journal of Heritage Studies 13(4-5):380-392.

Heinrich, J. 2000. Does culture matter in economic behaviour? Ultimatum game bargaining among the Machiguenga of the Peruvian Amazon. The American Economic Review 90(4):973-979.

Heinrich, J., R. Boyd, S. Bowles, C. Camerer, E. Fehr, H. Gintis, and R. McElreath. 2001. In search of Homo economicus: behavioural experiments in 15 small-scale societies. The American Economic Review 91(2):73-78.

Hodgson, M. G. S. 1974. The venture of Islam. Three volumes. University of Chicago Press, Chicago, Illinois, USA.

Holling, C. S. 1973. Resilience and stability of ecological systems. Annual Review of Ecology and Systematics 4:1-23.

Holling, C. S. 2001. Understanding the complexity of economic, ecological and social systems. Ecosystems 4:390-405.
Huntington, S. P. 1996. Clash of civilizations: the remaking of world order. Simon \& Schuster, New York, New York, USA.

International Crisis Group. 2009. Tajikistan: on the road to failure. Asia Report No. 162. 12 February. International Crisis Group, Brussels, Belgium.

Kallen, H. 1915. Democracy versus the melting pot. The Nation (February 18 and 25):190-4, 217-20.

Kassam, K.-A. S. 2009a. Biocultural diversity and indigenous ways of knowing: human ecology in the Arctic. University of Calgary Press, Calgary, Alberta, Canada.

Kassam, K.-A. S. 2009b. Viewing change through the prism of indigenous human ecology: findings from the Afghan and Tajik Pamirs. Human Ecology 37(6):377-390.

Kreutzmann, H. 2003. Ethnic minorities and marginality in the Pamirian Knot: survival of Wakhi and Kirghiz in a harsh environment and global contexts. The Geographical Journal 169(3):215235.

Langerak, E. 1994. Pluralism, tolerance, and disagreement. Rhetoric Society Quarterly 24 (1/2):95-106.

Lapidus, I. M. 1990. A history of Islamic societies. Cambridge University Press, Cambridge, UK.

Maffi, L. 2001. On the interdependence of biological and cultural diversity. Pages 1-50 in L. Maffi, editor. On biological diversity: linking languages, knowledge and the environment. Smithsonian Institution, Washington D.C., USA.

Maffi, L. 2002. Endangered languages, endangered knowledge. UNESCO, Blackwell Publishers, Oxford, UK.

Maffi, L. 2005. Linguistic, cultural and biological diversity. Annual Review of Anthropology 29:599617.

Mason, E. 2006. Value pluralism. In E. N. Zalta, editor. The Stanford Encyclopedia of Philosophy. Fall 2008 edition. [online] URL: http://plato.stanford. edu/entries/value-pluralism/.

Miller, T., T. D. Baird, C. M. Littlefield, G. 
Kofinas, F. S. Chapin III, and C. Redman. 2008. Epistemological pluralism: reorganizing interdisciplinary research. Ecology and Society 13(2):46. [online] URL: http://www.ecologyandsociety.org/vol13/iss2/ $\underline{\operatorname{art} 46 / .}$.

Mousseau, F. 2005. Food aid or food sovereignty? Oakland Institute, Oakland, California.

Murra, J. 1985a. The limits and limitations of the "Vertical Archipelago" in the Andes. Pages 3-13 in S. Masuda, I. Shimada, and C. Morris, editors. Andean ecology and civilization: an interdisciplinary perspective on Andean ecological complementarity. University of Tokyo Press, Tokyo, Japan.

Murra, J. 1985b. "El Archipielago Vertical" revisited. Pages 15-20 in S. Masuda, I. Shimada, and C. Morris, editors. Andean ecology and civilization: an interdisciplinary perspective on Andean ecological complementarity. University of Tokyo Press, Tokyo, Japan.

Naeem, S. 2002. Biodiversity equals instability? Nature 416:23-24.

Nanji, A. 1996. The Muslim almanac: a reference work on the history, faith, culture and peoples of Islam. Gale Group, New York, New York, USA.

Odum, E. P. 1989. Ecology and our endangered life-support systems. Sinauer Associates, Sunderland, Massachusetts.

Ostrom, E. 2000. Collective action and the evolution of social norms. Journal of Economic Perspectives 14(3):137-158.

Ostrom, E., J. Burger, C. B. Field, R. B. Norgaard, and D. Policansky. 1999. Revisiting the commons: local lessons, global challenges. Science 284:278-282.

Schlosberg, D. 1999. Environmental justice and the New Pluralism: the challenge of difference for environmentalism. Oxford University Press, Oxford, UK.

Shahrani, N. M. 1978. Ethnic relations and access to resources in Northeast Badakhshan. Pages 15-25 in J. Anderson and R. Strand, editors. Ethnic processes and intergroup relations in contemporary Afghanistan: papers presented at the Eleventh Annual Meeting of the Middle East Studies
Association (New York, 1977). Afghanistan Council of the Asia Society, New York, New York, USA.

Shahrani, N. M. 1979. The Kyrgyz and Wakhi of Afghanistan: adaptation to closed frontiers. University of Washington Press, Seattle, Washington, USA.

Smith, A. 1976 [1776]. An inquiry into the nature and causes of the wealth of nations. University of Chicago Press, Chicago, Illinois, USA.

Tilman, D., P. B. Reich, J. Knops, D. Wedin, T. Mielke, and C. Lehman. 2001. Diversity and productivity in a long-term grassland experiment. Science 294:843-845.

Turner, N., I. Davidson-Hunt, and $M$. O'Flaherty. 2003. Living on the edge: ecological and cultural edges as sources of diversity for socialecological resilience. Human Ecology 31(3):439461.

Walker, B., C. S. Holling, S. R. Carpenter, and A. Kinzig. 2004. Resilience, adaptability and transformability in social-ecological systems. Ecology and Society 9(2):5. [online] URL: http://w ww.ecologyandsociety.org/vol9/iss2/art5/.

Walker, B., and J. Meyers. 2004. Thresholds in ecological and social-ecological systems: a developing database. Ecology and Society 9(2):3. [online] URL: http://www.ecologyandsociety.org/vol9/ iss $2 / \operatorname{art} 3 /$.

Walker, B., and D. Salt. 2006. Resilience thinking: sustaining ecosystems and people in a changing world. Island Press, London, UK.

Windfuhr, M., and J. Jonsén. 2005. Food sovereignty: towards democracy in localized food systems. ITDG Publishing, Warwickshire, UK. 